\title{
Processing tomato waste as a potential bioactive compounds source: phenolic compounds, antioxidant capacity and bioacessibility studies
}

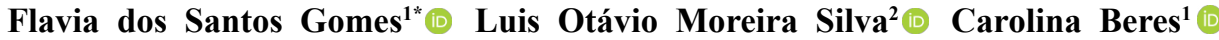 \\ Monica Marques Pagani ${ }^{2}$ (i) Ana Iraidy Santa Brígida ${ }^{3}$ (D) \\ Manuela Cristina Pessanha de Araújo Santiago ${ }^{1}$ (i) Sidney Pacheco $^{1}$ (i) \\ Ronoel Luiz de Oliveira Godoy ${ }^{1}$ (i) Lourdes Maria Corrêa Cabral ${ }^{1}$ (i)
}

${ }^{1}$ Embrapa Agroindústria de Alimentos, 23020-470, Rio de Janeiro, RJ, Brasil. E-mail: flavia.gomes@embrapa.br. "Corresponding author. ${ }^{2}$ Programa de Pós-graduação em Ciência e Tecnologia de Alimentos, Universidade Federal Rural do Rio de Janeiro (UFRRJ), Seropédica, RJ, Brasil. ${ }^{3}$ Embrapa Agroindústria Tropical, Fortaleza, CE, Brasil.

ABSTRACT: A comparative study was perfomed with conventional and ultrasound assisted extraction on tomato processing waste. Ultrasound extraction exhibited slightly higher phenolic and flavonoids content, as well as higher ABTS ${ }^{+}$radical scavenging capacity (4.63 mg GAE. ${ }^{-1}$,

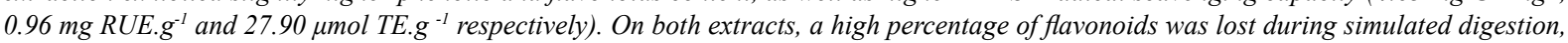
resulting on a bioacessibility of approximately $13 \%$. Extracts presented good stability during storage conditions, which indicates a possible technological application.

Key words: tomato, bioactive compounds, ultrasound-assisted extraction, conventional extraction, bioaccessibility.

Resíduo do processamento do tomate como potencial fonte de compostos bioativos: compostos fenólicos, capacidade antioxidante e bioacessibilidade

RESUMO: Foi realizado um estudo comparativo com a extração convencional e assistida por ultrassom em residuos do processamento de tomate. A extração ultrassônica exibiu teor de fenólicos e flavonóides ligeiramente maiores, bem como maior capacidade antioxidante ABTS + (4,63 mg AG. $\mathrm{g}^{-1}, 0,96 \mathrm{mg}$ RUE. $\mathrm{g}^{-1}$ e 27,90 $\mu \mathrm{mol} \mathrm{TE} . \mathrm{g}^{-1}$, respectivamente). Em ambos os extratos, uma alta porcentagem de flavonóides foi perdida durante a digestão simulada, resultando em uma bioacessibilidade de aproximadamente $13 \%$. Os extratos apresentaram boa estabilidade durante as condições de armazenamento, o que indica uma possível aplicação tecnológica.

Palavras-chave: tomate, compostos bioativos, extração assistida por ultrassom, extração convencional, bioacessibilidade.

In tomato (Lycopersicon esculentum Mill.) industrial processing, large amounts of waste (peels, seeds and pulp residue) are generated and account for 5 to $10 \%$ of the total tomato weight which represents a major environmetal and economical problem. Currently, feeding animals or its use as fertilizer are the most valuable way of re-usage of these residues (SENGAR et al., 2020). Although these wastes have no commercial value, they are a rich source of nutrients, colorants and highly biologically active compounds such as phenolics, flavonoids and carotenoids (COELHO et al., 2019). The extraction of these compounds represents an alternative for obtaining products with high added value, which can be used as ingredients in food, pharmaceutical and cosmetics industries. For example, phenols and carotenoids can be applied as natural colorants or natural antioxidants, antibrowning and antimicrobials agents in food and beverages (AYALA-ZAVALA\&GONZÁLEZ-AGUILAR,2011).

The most common methods for extracting bioactive compounds from agroindustrial processing wastes are based on the use of organic solvents (STRATI et al., 2014). However, ultrasound assisted extraction, a non conventional extraction has been used successfully with this purpose (PAINI et al., 2016). This method is recognized for being of lower process cost, of easy operation and faster extraction (WANG et al., 2006). In this way, the present study aimed to obtain extracts from tomato byproduct, using ultrasound and conventional extractions, and compare the bioactive potential, stability and flavonoids bioacessibility of the extracts. 
The tomato processing waste was obtained by depulping fresh tomatos (Lycopersicon esculentum Mill. cv. Carmem) (purchased at the local market of Rio de Janeiro - Brazil) in a Bonina 0,25 dF horizontal depulper (Itametal, Itabuna, Brazil) with a $1.5 \mathrm{~mm}$ diameter sieve. After depulping, the wet residue (peels and seeds) was dried in a convective dryer (Solab, São Paulo, Brazil) at $60^{\circ} \mathrm{C}$ for 24 hours. Seeds from dried byproduct were separated from the peels and simultaneously grounded into a powder using the Bonina $0.25 \mathrm{df}$ depulper. Peel powder was used for further analysis, and was characterized for particle size, moisture, antioxidant capacity, total phenolic compounds and total flavonoid content.

Particle size was determined in a SDCMicrotrac S3500 (Microtrac, Montgomeryville, PA, USA) using water as dispersant (AACC, 2010) and the results were expressed as mean diameter. Moisture was measured in a vacuum oven at $105^{\circ} \mathrm{C}$ for 24 hours (AOAC, 2016). The chemical analysis performed were: antioxidant activity by $\mathrm{ABTS}^{+}$. radical scavenging capacity method (RE et al., 1999) and by ORAC method (Oxygen Radical Absorbance Capacity) (ZULUETA et al., 2009), total phenolics content (SINGLETON \& ROSSI, 1965) and total flavonoid content (PEIXOTO SOBRINHO et al., 2008).

Extraction of bioactive compounds were carried out by two different methods using $70 \%(\mathrm{v} / \mathrm{v})$ ethanol:water as extraction solution. Conventional (C) extraction was performed according to THOO et al. (2013), on a thermostatic bath with a 430/RDBP orbital shaking (Nova Ética, São Paulo, Brazil) at $57^{\circ} \mathrm{C}$ and a solid/liquid ratio of $1: 25$ for 40 minutes. Ultrassound assisted (UA) extraction was performed on a $1000 \mathrm{~W}$ ultrasound equipment model UIP1000hd (Hielscher Ultrasonics, Teltow, Germany), with a titanium sonotrode BS2d18 (18 mm diameter) and a booster B4.18. The sonotrode was immersed $2 \mathrm{~cm}$ into the solution, with fixed parameters of $15 \mathrm{~min}$, power of $150 \mathrm{~W}$, frequency ranging between 60-62 $\mathrm{kHz}$ and initial temperature of $20^{\circ} \mathrm{C}$. Extractions were performed in triplicate and the extracts were vacuum filtered on qualitative paper for removing the suspended solids. The hydroalcoholic extracts were stored at $\left(6 \pm 1{ }^{\circ} \mathrm{C}\right)$ for subsequent analysis.

The in vitro static simulation included oral, gastric and intestinal digestion steps (GARRET et al., 1999) and was carried out in both extracts. The extract $(7 \mathrm{~mL})$ was mixed with a saliva solution containing digestive enzymes $\alpha$-amylase and mucin. For the gastric phase, the $\mathrm{pH}$ was adjusted to $2.5 \pm$ 0.1 and a pepsin solution was added (Porcine Pepsin, Sigma). The final intestinal phase had $\mathrm{pH}$ adjusted to
6.0 , and addition of a bile ( $4 \%$ ), pancreatin $(1 \%)$ and lipase $(0.5 \%)$ solution. Results were expressed as percentage of total flavonoids bioaccessibility and was determined by the ratio between the total flavonoids concentration after in vitro digestion and the total flavonoids concentration in the undigested extract.

For evaluation of storage stability, the extracts were placed in glass bottles and stored at two different temperatures: $-2{ }^{\circ} \mathrm{C}$ and $6{ }^{\circ} \mathrm{C}$. Flavonoids content was evaluated for a period of 28 days. Results were expressed as the ratio between the flavonoids content at each time and the initial flavonoids content $(\mathrm{C} / \mathrm{C} 0)$.

Data were subjected to Analysis of Variance (ANOVA) and Tukey test, with a significance level of $5 \%(\mathrm{P} \leq 0.05)$, using the Statistica 10.0 software (Statoft, Tulsa, USA). Analysis were made triplicate.

Peel powder exhibited a mean particle diameter of $483.4 \pm 15.7 \mu \mathrm{m}$ (Table 1 ). The particle size bimodal distribution indicated a heterogeneity of the tomato peel powder. VARDANEGA et al. (2019) observed that powder particle size distribution can be affected by the drying technique used. A larger size was expected since no grinding technique was used.

The low moisture content of tomato powder $(1.27 \%)$ suggested stability to the product and reduce the chance to microbiological degradation. According to REZAEI \& VANDERGHEYNST (2010), the limit for moisture content that inhibit microbial activity on tomato pomace ranges from 16 to $21 \%$ (dry basis).

Tomato residue, composed basically by peels and seeds, have been a rich source of phenolic compounds, being the phenolic acids and flavonoids the most abundant as reported by ĆETKOVIĆ et al. (2012). In this study, tomato peel powder presented $584.63 \pm 1.78 \mathrm{mg} \mathrm{GAE} . \mathrm{g}^{-1}$ of phenolic content. The total amount of phenolic compounds was found in the

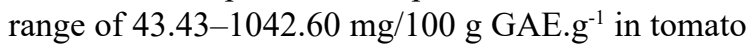
byproduct of different tomato varieties (PEREADOMÍNGUEZ et al., 2018; ROBLES-RAMÍREZ et al., 2016; NAVARRO-GONZÁLEZ et al., 2011 ).

Antioxidant capacity of peel powder was found as 700.67 and $186.98 \mu \mathrm{mol} \mathrm{TE} . \mathrm{g}-1$ for ORAC and ABTS + , respectively. This difference between the methods used was expected since characteristics such as chemical structure, molecular size, concentration of each compound in the sample interfere in electron transfer or hydrogen atom transfer which are the main mechanisms that measures the radical quenching capability of antioxidants (SCHAICH et al., 2015).

Phenolic content obtained using conventional extraction represented $76 \%$ of total phenolics recovery. The significant result is in accordance to the utilization of organic solvents, less 
Processing tomato waste as a potential bioactive compounds source: phenolic compounds, antioxidant capacity and bioacessibility studies. 3

Table 1 - Physical and chemical characterization of tomato peel powder and extracts.

\begin{tabular}{lccr}
\hline Analysis & Peel powder & Conventional extract (C) & Ultrasound extract (UA) \\
\hline $\mathrm{D}[4,3](\mu \mathrm{m})$ & $483.4 \pm 15.7$ & na & na \\
Moisture $\left(\mathrm{g} / 100 \mathrm{~g}^{-1}\right)$ & $1.27 \% \pm 0.23$ & na & na \\
TPC $\left(\mathrm{mg} \mathrm{GAE} .100 \mathrm{~g}^{-1}\right)$ & $584.63 \pm 1.78^{\mathrm{a}}$ & $445.95 \pm 0.95^{\mathrm{c}}$ & $463.16 \pm 1.58^{\mathrm{b}}$ \\
TFC $\left(\mathrm{mg} \mathrm{RUE} .100 \mathrm{~g}^{-1}\right)$ & $\mathrm{nd}$ & $94.25 \pm 0.01^{\mathrm{a}}$ & $95.75 \pm 0.07^{\mathrm{b}}$ \\
ABTS $^{+}\left(\mu \mathrm{mol} \mathrm{TE} . \mathrm{g}^{-1}\right)$ & $186.98 \pm 1.78^{\mathrm{a}}$ & $25.92 \pm 0.11^{\mathrm{c}}$ & $27.90 \pm 0.10^{\mathrm{b}}$ \\
ORAC $\left(\mu \mathrm{mol} \mathrm{TE} . \mathrm{g}^{-1}\right)$ & $700.67 \pm 17.47^{\mathrm{a}}$ & $97.13 \pm 12.44^{\mathrm{b}}$ & $109.82 \pm 15.03^{\mathrm{b}}$ \\
\hline
\end{tabular}

$\mathrm{D}[4,3]$ - volume mean diameter; TPC - total phenolic content; TFC - total flavonoids content; GAE - gallic acid equivalents; RUE rutin equivalents; ORAC - Oxygen Radical Absorbance Capacity; ABTS ${ }^{+.}$- 2,2'-azinobis-(3-ethylbenzothiazoline-6-sulphonate), TE Trolox equivalents. Values are the mean of three replicates of three independent experiments. Same letter within the same line are not statistically different (Tukey test; $\mathrm{P} \leq 0.05$ ); na: not applicable; nd: not determined.

polar than water, which improves the polyphenols extraction (HAMINIUK et al., 2014). Ultrasound extraction achieved a recovery of phenolic compounds slightly higher $(\mathrm{P}<0.05)$ than conventional extraction in a shorter time $(10 \mathrm{~min})$ (Table 1$)$. The temperature probe achieved $82^{\circ} \mathrm{C}$ in ten minutes, so the extraction was interrupted. In this study, 10 min of ultrasound assisted extraction was enough to extract similar phenolic content than the obtained in $40 \mathrm{~min}$ of conventional extraction. The ultrasound waves cause disruption in the plant tissue through physical forces developed during acoustic cavitation and helps the release of extractable components in very less time by enhancing the mass transfer of the analyte to the solvent (ASHOKKUMAR, 2015).

As the ground residue, higher ORAC values in comparison to ABTS + . method were obtained for the conventional and ultrasound extracts. The antioxidant capacity of tomato byproduct can not be attributed to a specific phenolic compound or to a class of phenolic compounds. This ability could be related to the mutual interactions of all hydrophillic antioxidants and other constituents of the tomato extracts (ĆETKOVIĆ et al., 2012).

Aproximately $21 \%$ of the phenolic compounds presented in the conventional and ultrasound assisted extracts in the present research is represented by flavonoids ( 94.25 and $95.75 \mathrm{mg}$ RUE $\mathrm{g}^{-1}$, respectivelly), in accordance to previous studies which indicated that tomato peels are an interesting source of several flavonoids like rutin, naringenin and quercetin that have been associated to health promoting effects(SAVATOVIĆ etal., 2012). In this case rutin was chosen to be the compound tested for bioacessibility.

After simulated gastrointestinal digestion, the total flavonoids bioacessibility were 13.59 and
$13.72 \%$ for the US and C extracts, respectively. These values are considered quite low, in comparison to other studies for plant extracts, where flavonoids bioaccessibility vary from 30 to $100 \%$ (NETO et al., 2017). The loss observed may have ocurred during oral digestion step due to the formation of insoluble aggregates, caused by an interaction between salivary proteins and polyphenols (PINEDA-VADILLO et al., 2016; SARNI-MANCHADO et al., 1999). LI et al. (2014) observed a complete degradation or significant reduction of major phenolic compounds, including rutin on tomatoes during gastric digestion. Finally, the transition from acidic gastric conditions to the mild alkaline intestinal environment, containing bile acids and pancreatin may also induce the degradation of phenolic compounds (GUNATHILAKE et al., 2018).

The storage stability of the ethanolic extracts obtained by conventional and UA extraction was evaluated. Although, significative differences $(\mathrm{P}<0.05)$ were observed, no remarkable changes in total flavonoids content occurred throughout the time (Figure 1).

Flavonoids content of conventional extracts stored at $-2{ }^{\circ} \mathrm{C}$ remained stable for 21 days of storage. After 28 days, a percentual retention around $94 \%$ was observed. In contrast, the conventional extracts remained stable in the refrigerated storage for 7 days, but, at the end of the storage, flavonoids retention was still $92 \%$.

UA extracts stored at $-2{ }^{\circ} \mathrm{C}$ did not show significant differences $(\mathrm{P}>0.05)$ in the flavonoids content throughout time. A slightly decrease in total flavonoids content was observed for the extracts stored at $6{ }^{\circ} \mathrm{C}$ after 28 days. After this time, the extracts presented a percentual retention of $94.5 \%$ and total flavonoids content was not directly affected ( $\mathrm{P}>$ 0.05 ) by the storage temperature used in the study. 


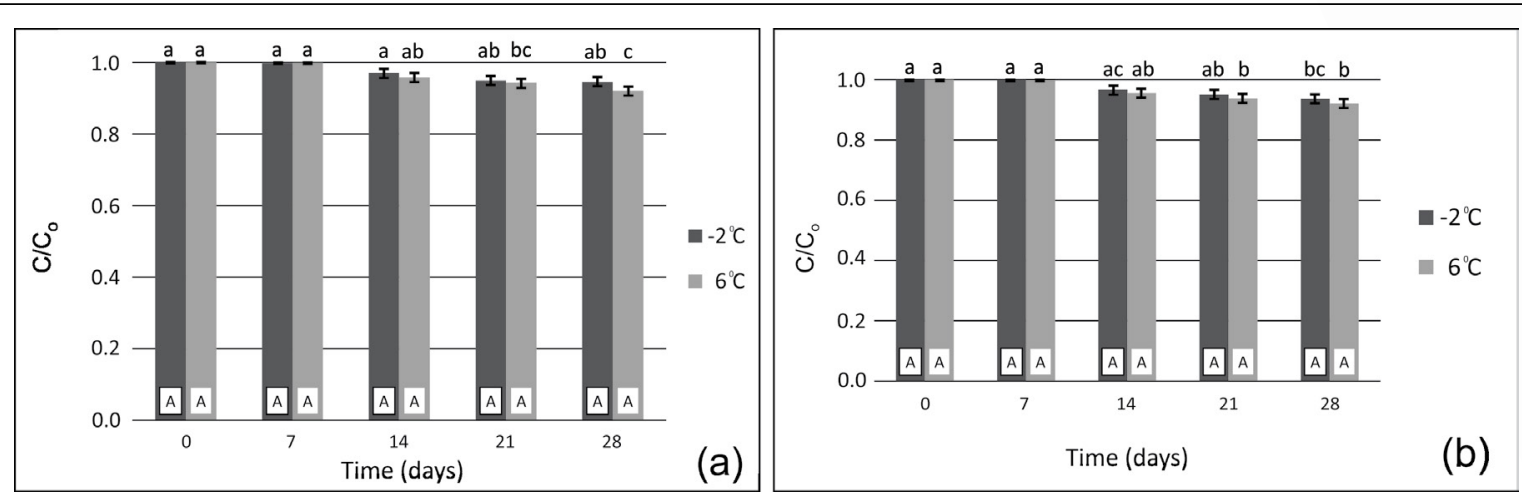

Figure 1 - Relative flavonoids content in (a) Conventional and (b) UA extracts along storage at $-2{ }^{\circ} \mathrm{C}$ and $6{ }^{\circ} \mathrm{C}$. Different lower case letters indicate significant difference (Tukey test, $\mathrm{P} \leq 0.05$ ) between different samples. Same capital letters indicates no significant differences (Tukey test, $\alpha=0.05$ ).

Ultrasound showed to be a promising alternative for the extraction of total phenolic compounds from tomato byproduct, allowing the production of extracts rich in these compounds, with antioxidant potential. Besides, ultrasound could be claimed as more efficient due to a shorter extraction time.

\section{ACKNOWLEDGEMENTS}

The authors would like to thank the Programa de Pósgraduação em Ciência e Tecnologia de Alimentos of Universidade Federal Rural do Rio de Janeiro (UFRRJ) and Embrapa Agroindústria de Alimentos for supporting this research financed in part by the Coordenação de Aperfeiçoamento de Pessoal de Nível Superior (CAPES), Brasil - Finance code 001".

\section{DECLARATION OF CONFLICT OF} INTEREST

The authors declare no conflict of interest. The founding sponsors had no role in the design of the study; in the collection, analyses, or interpretation of data; in the writing of the manuscript, and in the decision to publish the results.

\section{AUTHORS' CONTRIBUTIONS}

The authors contributed equally to the manuscript.

\section{REFERENCES}

AACC International. (2010). Particle size of wheat flour by laser instrument. Approved Methods of Analysis, (11 ed). Method 5540.01. Approved November 1, 1989. Reapproval November 3, 1999. St. Paul: AACC International.

Association of Official Analytical Chemists (AOAC). In: Official methods of analysis of AOAC International. 20 ed.: AOAC, 2016.
ASHOKKUMAR, M. Applications of ultrasound in food and bioprocessing. Ultrasonics Sonochemistry, v.25, p.17-23, 2015. Available from: $<$ https://doi.org/10.1016/j.ultsonch.2014.08.012>. Accessed: Mar. 18, 2020. doi: 10.1016/j.ultsonch.2014.08.012.

ĆETKOVIĆ, G. et al. Valorisation of phenolic composition, antioxidant and cell growth activities of tomato waste. Food Chemistry, n.133, p.938-945, 2012. Available from: $<$ https://doi. org/10.1016/j.foodchem.2012.02.007>. Accessed: Sep. 14. doi: 10.1016/j.foodchem.2012.02.007.

COELHO, M. et al. Extraction of tomato by-products' bioactive compounds using ohmic technology. Food and Bioproducts Processing, n.117, p.329-339, 2019. Avaiable from: <https://doi. org/10.1016/j.fbp.2019.08.005>. Accessed: Mar. 15, 2020. doi: 10.1016/j.fbp.2019.08.005.

GARRET, D. A. et al. Development of an in vitro digestion model of estimating the bioavailability of carotenoids from meals. Journal of Agriculture and Food Chemistry, v.47, p.43014309, 1999. Available from: <https:// doi: 10.1021/jf9903298>. Accessed: Aug. 6, 2020. doi: 10.1021/jf9903298.

GUNATHiLAKE, K. D. P. P. et al.. Change of phenolics, carotenoids, and antioxidant capacity following simulated gastrointestinal digestion and dialysis of selected edible green leaves. Food Chemistry, v.245, p.371-379, 2018. Available from: $<$ https://pubmed.ncbi.nlm.nih.gov/29287383/>. Accessed: Sep. 16, 2020. doi: 10.1016/j.foodchem.2017.10.096.

HAMINIUK, C. W. I. et al. Extraction and quantification of phenolic acids and flavonols from Eugenia pyriformis using different solvents. Journal of Food Science Technology, v.51, p.2862-2866, 2014. Available from: <https:// doi: 10.1007/s13197012-0759-z>. Acessed: Sep. 16, 2020. doi: 10.1007/s13197-0120759-z.

LI, H. et al.. Bioaccessibility, in vitro antioxidant activities and in vivo anti-inflammatory activities of a purple tomato (Solanum lycopersicum L.). Food Chemistry, v.159, 353-360, 2014. Available from: <https://doi: 10.1016/j.foodchem.2014.03.023>. Accessed: Sep. 20, 2020. doi: 10.1016/j.foodchem.2014.03.023. 
NAVARRO-GONZÁLEZ, I. Chemical profile, functional and antioxidant properties of tomato peel fiber. Food Research International, v.44, p.1528-1535, 2011. Available from: $<$ https:// doi:10.1016/j.foodres.2011.04.005>. Accessed: Mar. 18, 2020. doi: 10.1016/j.foodres.2011.04.005.

NETO, J. L. et al. Impact of bioaccessibility and bioavailability of phenolic compounds inbiological systems upon the antioxidant activity of the ethanolicextract of Triplaris gardneriana seeds. Biomedicine \& Pharmacotherapy, v.88, p.999-1007, 2017. Available from: <https://doi:10.1016/j.biopha.2017.01.109. Accessed: Sep. 18, 2020. doi: 10.1016/j.biopha.2017.01.109.

PAINI, M. et al. Influence of ethanol/water ratio in ultrasound and high pressure/high temperature phenolic compound extraction from agrifood waste. International Journal of Food Science and Technology, v.51, p.349-358, 2016. Available from: $<$ https:// doi:10.1111/ijfs.12956>. Accessed: Sep. 22, 2020. doi: 10.1111/ ijfs.12956.

PEIXOTO SOBRINHO, T J S. Validation of spectrophotometric methodology for quantify flavonoid content in Bauhinia cheilantha (Bongard). Revista Brasileira de Ciências Farmacêuticas, v.44, n.4, p.683-689, 2008., vol.44, n.4, 2008. Available from: <https:// doi.org/10.1590/S1516-93322008000400015>. Accessed: Sep. 19, 2020. doi: $10.1590 / \mathrm{S} 1516-93322008000400015$.

PEREA-DOMÍNGUEZ, X. P. et al. Phenolic composition of tomato varieties and an industrial tomato by-product: free, conjugated and bound phenolics and antioxidant activity. Journal of Food Science and Technology, v.55, n9, p.3453-3461, 2018. Available from: $<$ https://doi.org/10.1007/s13197-018-3269-9>. Accessed: Mar. 18, 2020. doi: 10.1007/s13197-018-3269-9.

PINEDA-VADILLO et al. In vitro digestion of dairy and egg products enriched with grape extracts: Effect of the food matrix on polyphenol bioaccessibility and anti-oxidant activity. Food Research International, v.88, p.284-292, 2016. Available from: $<$ https://doi.org/10.1016/j.foodres.2016.01.029>. Accessed: Sep. 22, 2020. doi: 10.1016/j.foodres.2016.01.029.

REZAEI, F; VANDERGHEYNST, J.S. Critical moisture content for microbial growth in dried food-processing residues. Journal of the Science and Food Agriculture, v.90, p.2000-2005, 2010. Available from: <https://pubmed.ncbi.nlm.nih.gov/20597097/>. Accessed: Mar. 5, 2020. doi 10.1002/jsfa.4044.

RE R. et al. Antioxidant activity applying an improved abts radical cation decolorization assay. Free Radical Biology \& Medicine, v.26, p.1231-1237, 1999. Available from: <https://doi.org/10.1016/ S0891-5849(98)00315-3>. Accessed: Aug. 22, 2020. doi: 10.1016/ S0891-5849(98)00315-3.

ROBLES-RAMíREZ, M. C.et al. Evaluation of extracts from potato and tomato wastes as natural antioxidant additives. Archivos Latinoamericanos de Nutrición, v.66, n.1, p.66-73, 2016. Available from: <http://ve.scielo.org/scielo.php?script=sci arttext\&pid=S0004-06222016000100008\&lng $=$ es\&nrm=iso $>$. Accessed: Mar. 18, 2020.
SARNI-MANCHADO, P. Interactions of grape seed tannins with salivary proteins. Journal of Agricultural and Food Chemistry, v.47, p.42-47, 1999. Available from: <https://doi.org/10.1021/ jf9805146>. Accessed: Oct. 2, 2020. doi: 10.1021/jf9805146.

SAVATOVIĆ, S. et al. Tomato waste: A potential source of hydrophilic antioxidants. International Journal of Food Sciences and Nutrition, v.63, p.129-137, 2012. Available from: <https:// doi.org/10.3109/09637486.2011.606211>. Accessed: Sep. 2, 2020. doi: $10.3109 / 09637486.2011 .606211$.

SCHAICH, K. M. et al. Hurdles and pitfalls in measuring antioxidant efficacy: A critical evaluation of ABTS, DPPH, and ORAC assays. Journal of Functional Foods, v.14, p.111-125, 2015. Available from: <https://doi.org/ 10.1016/j.jff.2015.01.043>. Accessed: Sep. 2, 2020. doi: 10.1016/j.jff.2015.01.043.

SENGAR, A. S. Comparison of different ultrasound assisted extraction techniques for pectin from tomato processing waste. Ultrasonics Sonochemistry, v.61, 2020, 104812, 2020. Available from: $\quad<$ https://doi.org/10.1016/j.ultsonch.2019.104812>. Accessed: Sep. 12, 2020. doi: 10.1016/j.ultsonch.2019.104812.

SINGLETON, V. L.; ROSSI, J. A. Colorimetry of total phenolics with phosphomolybdic-phosphotungstic acid reagents. American Journal of Enology and Viticulture, v.16, p.144-168, 1965. Available from: <https://www.ajevonline.org/content/16/3/144>. Accessed: Aug. 10, 2020.

STRATI, I. F. et al. Recovery of carotenoids from tomato processing by-products - a review. Food Research International, Athens, v.65, p.311-321, 2014. Available from: https://doi.org/10.1016/j. foodres.2014.09.032>. Accessed: Sep. 10, 2020. doi: 10.1016/j. foodres.2014.09.032.

THOO, Y. Y. et al. Optimal binary solvent extraction system for phenolic antioxidants from Mengkudu (Morinda citrifolia) fruit. Molecules, v.18, n.6, p.7004-7022, 2013. Available from: <https:// doi.org/10.3390/molecules18067004>. Accessed: Sep. 10, 2020. doi: $10.3390 /$ molecules 18067004

VARDANEGA, R. et al. Obtaining functional powder tea from Brazilian ginseng roots: Effects of freeze and spray drying processes on chemical and nutritional quality, morphological and redispersion properties. Food Research International, 116, 932-941, 2019. Available from: <https:// doi.org/10.1016/j.foodres.2018.09.030>. Accessed: Sep. 15, 2020. doi: 10.1016/j.foodres.2018.09.030.

WANG, L. et al. Recent advances in extraction of nutraceuticals from plants. Trends in Food Science and Technology, v.17, n.6, p.300- 312, 2006. Available from: <https://doi.org/10.1016/j. tifs.2005.12.004>. Accessed: Sep. 15, 2020. doi: 10.1016/j. tifs.2005.12.004

ZULUETA, A. et al. ORAC and TEAC assays comparison to measure the antioxidant capacity of food products. Food Chemistry, v.114, p.310-316, 2009. Available from: $<$ https://doi. org/10.1016/j.foodchem.2008.09.033>. Accessed: Sep. 2, 2020. doi: 10.1016/j.foodchem.2008.09.033. 